\title{
Influence of the level of dietary phosphorus on the voluntary intake of energy and metabolic utilization of nutrients in the growing rat
}

\author{
By Y. HENRY, L. GUEGUEN and A. RERAT \\ Station de Recherches sur l'Elevage des Porcs, Station de Recherches de Nutrition and Labora- \\ toire de Physiologie de la Nutrition, INRA 78350 Jouy-en-Josas, France
}

(Received 5 July 1978 - Accepted I5 February 1979)

\begin{abstract}
I. An experiment was carried out on growing male rats to study the effects of a phosphorus deficiency on voluntary energy intake, estimated by the separate-feeding technique, as well as the consequences on growth and metabolic utilization of energy, protein and minerals. After a preliminary period of $\mathbf{P}$ deprivation, three groups of twelve animals were fed separately and simultaneously two dietary rations. A protein ration provided $\mathrm{I} \cdot 2 \mathrm{~g}$ protein $/ \mathrm{d}$ to which was added one of three levels of $\mathrm{P}$ in the form of monosodium phosphate: a normal level of $35.4 \mathrm{mg} / \mathrm{d}$ (treatment $\mathrm{A}$ ), half the normal level (19.1 $\mathrm{mg} / \mathrm{d}$, treatment B) or one-quarter the normal level $(9.6 \mathrm{mg} / \mathrm{d}$, treatment C). Another protein-free ration was fed ad lib.

2. It was only when the level of $P$ represented one quarter the normal level that a significant decrease in growth rate was noticed, accompanied by a definite decrease in daily energy consumption. The food conversion ratio ( $\mathrm{g}$ dry matter intake/g body-weight gain) increased whereas the protein efficiency ratio ( $\mathrm{g}$ bodyweight gain/g protein intake) was lower. The nitrogen and energy retentions changed in the same way: both decreased with treatment $\mathrm{C}$ compared to treatments $\mathrm{A}$ and $\mathrm{B}$. Independently of the protein supply, the voluntary energy intake was closely related to the intensity of protein retention, which depended on the dietary level of $P$. The daily retention of $P$ only slightly decreased at the lowest ingestion level $(9.6 \mathrm{mg} / \mathrm{d}$ in treatment C), compared to that of the higher levels. On the other hand, the amount of calcium retained regularly decreased with the decreasing supply of $P$. The result of this was a progressive reduction in retained $\mathrm{Ca}: \mathrm{P}$ as the level of $\mathbf{P}$ decreased.

3. From these results it appeared that the primary effect of a $P$ deficiency in the growing rat was a decrease in bone mineralization. At a more advanced stage, the tissue $\mathbf{P}$ levels were affected and the resulting metabolic alterations reduced protein deposition and consequently the voluntary energy intake. The level of energy consumption, in separate-feeding, is more generally dependent on the level of protein deposition allowed by the limiting factor for growth, either protein, minerals or vitamins.
\end{abstract}

It is a well-known fact that the level of food intake in the animal is closely balanced to its energy requirement (Mayer, I964), although the question has been raised whether the adjustment of food intake would imply separate mechanisms for regulating the ingestion of specific nutrients, mainly energy-yielding substances and protein. When the animals are allowed to self-select both protein and energy intakes from rations containing or not containing protein source (Henry \& Rérat, 1963; Henry, 1968; Rozin, 1968) or varying only in protein source and content (Rosen \& Levinger, 1972; Musten et al. 1974; Ashley \& Anderson, 1975; Szepesi \& Oney, 1977), it was observed that protein intake was separately regulated from energy intake, and that both controlling mechanisms interacted in determining food intake. In order to dissociate these interacting mechanisms the separate-feeding technique has been used to study the adjustment of energy consumption for a controlled amount of protein supply. Considering the growing albino rat, when fed separately and simultaneously two dietary rations, a protein ration in a limited amount and a protein-free ration ad lib. the voluntary energy intake has been shown to be closely adjusted to the quantity and the quality of protein supply, and more specifically to the growth rate and the level of nitrogen retention allowed by the protein supply (Henry \& Rérat, I962, 1966; Rérat \& Henry, 1963; Rérat et al. 1963; Pol \& Den Hartog, 1966; Jacquot \& Péret, 1972). Furthermore, a deficiency in some B-vitamins (thiamin, riboflavin) was associated with a modification of the level of energy intake which remained dependent on the $\mathrm{N}$ retained in the tissues (Henry \& Rérat, 1964, 1969). This was also the situation after vitamin A depri- 


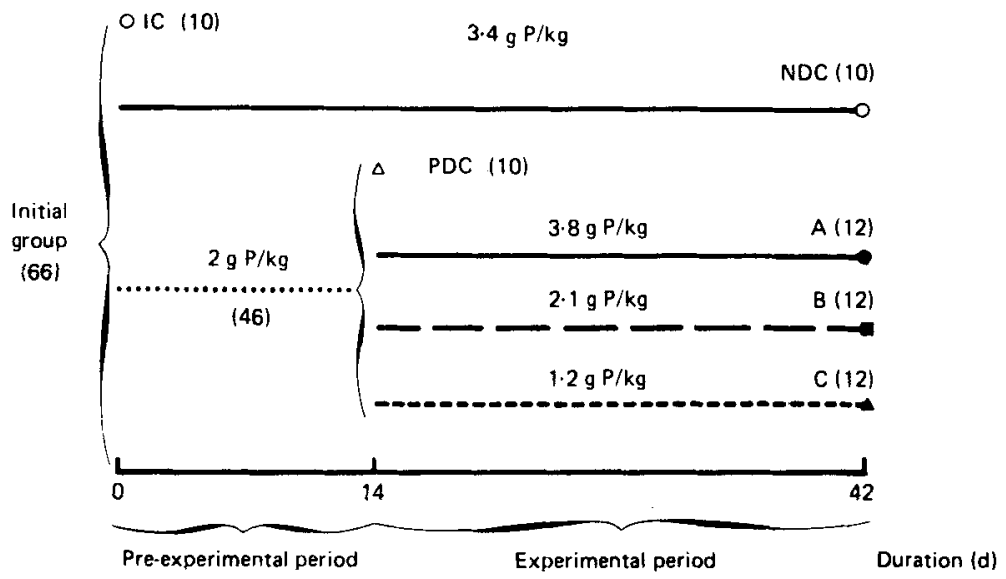

Fig. I. Experimental design. Normal diet (-); phosphorus-deficient: mild deficiency (- -); severe deficiency $(\ldots)$; age $5 \mathbf{I}-52 \mathrm{~d}$ when killed $(O, 0, \mathbf{D}, \mathbf{\Delta})$; no of animals/treatment in parentheses. IC, NDC, PCD, A, B, C, treatment groups (for details of dietary composition for various treatments, see Table I).

vation (Blaizot \& Blaizot, 1969). It may be questioned whether the level of voluntary energy intake is more generally influenced by other nutritional factors than protein and vitamins, such as minerals, which may change directly or indirectly the intensity of protein synthesis. The present experiment was designed to study the effect of the severity of $\mathbf{P}$ deficiency on the voluntary energy intake and the utilization of nutrients (energy, protein and minerals) in the growing rat, the daily protein intake being kept constant by means of the separate-feeding technique.

\section{MATERIALS AND METHODS}

Sixty-six weaned male albino rats of the Wistar CF strain, between 23 and $24 \mathrm{~d}$ of age and with a mean body-weight of $42.3 \mathrm{~g}$ were divided into three homogenous groups (Fig. I). A group of ten animals (group IC) was killed immediately after an $8 \mathrm{~h}$ fast and was used as a control for the initial body composition. A second group of forty-six rats was subjected to a severe deficiency in $\mathbf{P}$ with the aim of obtaining a depletion of the body reserves. For this purpose the animals were fed individually in two separate troughs the following two dietary rations: a severely-P-deficient protein ration (in restricted amount) and a proteinfree P-free ration ad lib.

A third group of ten animals, 'non-deficient control' (NDC), receiving P-containing diets, was kept under the same conditions of separate-feeding as the previous group; $48 \mathrm{~g}$ monosodium phosphate $/ \mathrm{kg}$ were introduced into the protein ration corresponding to a predicted daily $P$ intake of $36 \mathrm{mg}$.

The protein ration contained $400 \mathrm{~g}$ protein in the form of egg-albumin powder $/ \mathrm{kg}$ and the animals received $3 \mathrm{~g} / \mathrm{d}$ at $09 \cdot 00$ hours, corresponding to an ingestion of $\mathrm{I} \cdot 2 \mathrm{~g}$ protein. A mineral mixture without P, prepared according to Day \& McCollum (I939), was added at a level of $I 20 \mathrm{~g} / \mathrm{kg}$ in order to meet the requirements of the rat for the other minerals. The egg-albumin powder was chosen because of its low $P$ content $(0.94 \mathrm{mg} / \mathrm{g})$ contrasting with the high biological value of its protein ( 97 for the growing rat, according to Mitchell, 1959).

The protein-free ration contained sucrose, peanut oil, purified wood cellulose and 
Table I. Composition $(\mathrm{g} / \mathrm{kg})$ of experimental diets

Dietary ration $\ldots$

Treatment group ...

Phosphorus level ...

Crude protein (nitrogen $\times 6.25$ )

Ingredients

Egg-albumin powder $\uparrow$

Sucrose

Peanut oil (+ retinol and ergocalciferol) $\ddagger$

Powdered wood cellulose

Vitamin mixture

Mineral mixture $P$-free $\$$

$\mathrm{Na}_{2} \mathrm{HPO}_{4}$

Mean analytical results

Dry matter (DM) $(\mathrm{g} / \mathrm{kg})$

$\mathrm{N}$ (g/kg DM)

Gross energy ( $\mathrm{kJ} / \mathrm{g}$ DM)

$P$ (mg/g fresh wt)

Calcium ( $\mathrm{mg} / \mathrm{g}$ fresh wt)

Potassium (mg/g fresh wt)

Sodium (mg/g fresh $\mathrm{wt}$ )

- $35 \mathrm{mg} \mathrm{P} / \mathrm{d}$.

† Composition (g/kg): $930.7 \mathrm{DM}, 801$ crude protein, $0.85 \mathrm{Ca}, 0.94 \mathrm{P}, 10.2 \mathrm{~K}, 12.2 \mathrm{Na}$ (Ets François 94100-St-Maur-les-Fossés).

$¥$ Contributed $(\mu \mathrm{g} / \mathrm{kg}$ diet) retinol 5250 , ergocalciferol $87 \cdot 5$.

II Composition $(\mathrm{mg} / \mathrm{kg})$ : thiamin hydrochloride 8 , nicotinic acid 30 , pyridoxine 8 , riboflavin 15 , calcium pantothenate 30 , cyanocobalamin 0.03 , pteroylmonoglutamic acid $\mathrm{I}$, inositol $500, p$-aminobenzoic acid 500, $\alpha$-tocopherol 30, 2-methyl-I,4-napthoquinone 5, biotin 0.2 . Maize starch was added to a final amount of $10 \mathrm{~g}$ mixture $/ \mathrm{kg}$ diet). Choline chloride was added as $20 \%(\mathrm{w} / \mathrm{v})$ solution at the rate of $5 \mathrm{ml} / \mathrm{kg}$ diet.

$\S$ Composition $(\mathrm{g} / \mathrm{kg}): \mathrm{NaCl} 23 \cdot 7 \mathrm{I}, \mathrm{KCl}{ }_{13} \cdot 23, \mathrm{CaCO}_{3} 24.55, \mathrm{MgSO}_{4} 9 \cdot 37$, ferric citrate $3 \cdot 20, \mathrm{CuSO}_{4}$. $5 \mathrm{H}_{2} \mathrm{O} 0.32, \mathrm{MnSO}_{4} .2 \mathrm{H}_{2} \mathrm{O} 0 \cdot 1 \mathrm{O}, \mathrm{ZnSO}_{4}, 0.50, \mathrm{KI} 0.02$.

This formula is comparable to that proposed by Day \& McCollum (1939), $\mathrm{Na}$ and Kcontents being reduced because of their high levels in egg-albumin.

vitamins, but no minerals. Its composition, as well as that of the protein ration P-deficient (PD), is described in Table $\mathrm{I}$.

After a few days, when the animals ate all the protein offered, the group receiving the P-deficient diet showed a slight initial delay in growth as compared with the control group (Fig. 2). As the depletion period progressed, growth continued, although at a lower rate, and the animals refused to eat the total amount of protein. At the end of this period, which lasted I $4 \mathrm{~d}$, four groups from the depleted rats were formed taking into account the bodyweight and weight gain achieved during the pre-experimental period. A control P-deficient group of ten animals (PDC) was killed immediately after an $8 \mathrm{~h}$ fast, whereas the three other treatments $(\mathrm{A}, \mathrm{B}, \mathrm{C})$, each containing twelve animals, received for $28 \mathrm{~d}$, in two separate meals, $\mathrm{I} \cdot 2 \mathrm{~g}$ egg-albumin protein $/ \mathrm{d}$ as well as energy ad lib. and a variable supply of $\mathrm{P}$ in the form of monosodium phosphate: treatment $A, 35.4 \mathrm{mg} / \mathrm{d}$, rather close to the recommended level for growth ( $50 \mathrm{mg} / \mathrm{d}$ according to the US National Research Council, 1972); treatments $B$ and $C$, half $(19.1 \mathrm{mg})$ and one-quarter $(9.6 \mathrm{mg})$ of the normal level respectively (Table I).

The daily supply of calcium was maintained at approximately $45 \mathrm{mg} / \mathrm{d}$ whatever the level of $\mathbf{P}$. 

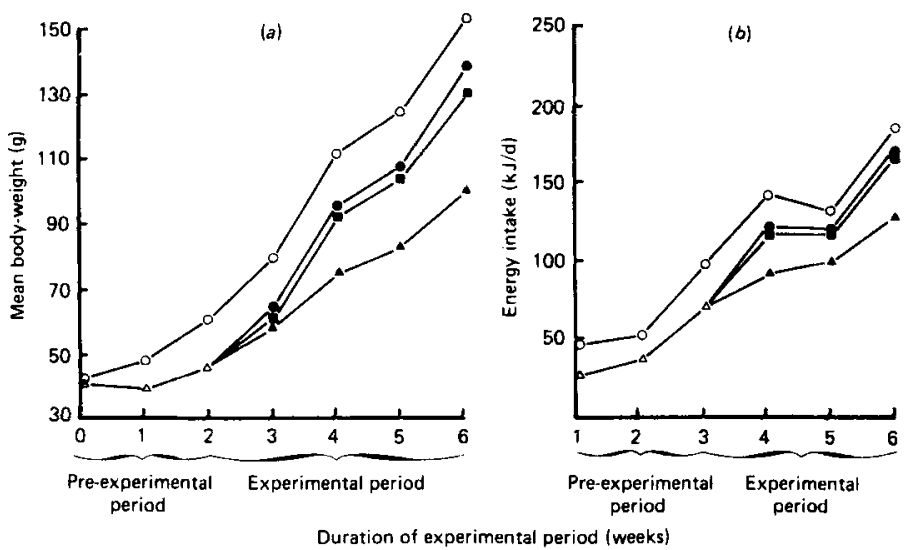

Fig. 2. The effect of dietary phosphorus level on $(a)$ growth $(\mathrm{g})$ and $(b)$ energy consumption $(\mathrm{kJ} / \mathrm{d})$ of growing rats estimated by the separate-feeding technique (for details, see p. I 28 and Fig. I). Each point represents the mean of twelve rats per treatment except for control (ten animals). $\bigcirc-O$, control; $\triangle \longrightarrow \triangle$, initial deficiency; $-O$, treatment group $\mathbf{A} ; \mathbf{-}-\mathbf{m}$, treatment group $\mathbf{B}$; $\Delta-\Delta$, treatment group $C$.

The consumptions of the protein and protein-free dietary rations were recorded every day and the animals were weighed twice per week. At the end of the 4-week experimental period, the animals were killed after an $8 \mathrm{~h}$ fast and whole carcasses were frozen and stored at $-15^{\circ}$, like those of the control groups. After sectioning into several fragments, the carcasses were individually ground in a meat grinder (Bauknecht) and finely homogenized with a hand masticator. Chemical analyses were performed in triplicate on aliquot samples: dry matter (DM) after drying to constant weight at $95^{\circ}$ during $48 \mathrm{~h}$, ash after $36 \mathrm{~h}$ incineration at $350^{\circ}$ and $\mathrm{N}$ according to the macro Kjeldahl procedure. The lipid content was estimated by difference after subtracting protein $(\mathrm{N} \times 6.25)$ and ash from $\mathrm{DM}$, the carbohydrate fraction of the body being assumed to be negligible (Mickelsen \& Anderson, 1959). In a previous comparative test (Henry \& Rérat, 1963) it was found that the values given by this method of estimating the lipid content by difference were close to and only $3 \%$ higher than those obtained by the direct analysis of the lipid fraction. The energy content of the carcass as well as of the diets was calculated from protein and lipid contents by using the 5.65 and 9.4 factors respectively (Atwater \& Bryant, 1903). Energy and $\mathrm{N}$ retentions were calculated from the results of body composition at the beginning and at the end of the experiment. Mineral analyses in the whole carcass were performed after dry ashing by means of a flame spectrophotometer (Eppendorf) for $\mathrm{Ca}$, sodium and potassium, and by colorimetric determination of ammonium phosphovanadomolybdate for $\mathrm{P}$. Thereafter, $\mathrm{P}$ and $\mathrm{Ca}$ balances were calculated in the same way as for protein and energy.

Statistical treatment of experimental results was carried out by the usual method of analysis of variance and multiple comparison of treatment means when possible (Snedecor \& Cochran, 1967), using Pearson \& Hartley's (1956) tables. More generally, the variability of each treatment mean is indicated by the standard error of the mean. 
Table 2. The effect of dietary phosphorus levels on growth, food consumption and food conversion efficiency of growing rats during the $28 \mathrm{~d}$ experimental period, estimated by the separate-feeding technique*

Mean values with their standard errors for ten animals in control group and for twelve animals in treatment groups $\mathrm{A}-\mathrm{C}$ )

Pre-experimental period

P status ....

Experimental period:

Treatment group $\dagger$... Non-deficient control

(NCD)

Non-deficient

Normal

P level $\ldots$
Body-weight (g):
Initial
Final

Mean daily wt gain (g)

Nitrogen intake (mg/d)

$P$ intake $(\mathrm{mg} / \mathrm{d})$

Dry matter intake $(\mathrm{g} / \mathrm{d})$

Gross energy intake $(\mathrm{kJ} / \mathrm{d})$

Food conversion ratio $\ddagger$

\begin{tabular}{|c|c|}
\hline \multicolumn{2}{|c|}{ Normal } \\
\hline Mean & SE \\
\hline $6 I \cdot 2$ & 3.5 \\
\hline $154^{\circ} 0$ & $2 \cdot 8$ \\
\hline $3.31^{\mathrm{a}}$ & 0.06 \\
\hline $\begin{array}{r}190.8 \\
34.4\end{array}$ & $\begin{array}{l}1.0 \\
0.3\end{array}$ \\
\hline $10 \cdot 2^{\mathrm{a}}$ & 0.24 \\
\hline $188^{a}$ & $4 \cdot 3$ \\
\hline $3.09^{\mathrm{a}}$ & 0.10 \\
\hline $2 \cdot 70^{\mathrm{a}}$ & 0.08 \\
\hline
\end{tabular}

\begin{tabular}{|c|c|c|c|c|c|}
\hline \multicolumn{2}{|c|}{ Normal } & \multicolumn{2}{|c|}{$0.5 \times$ normal } & \multicolumn{2}{|c|}{$0.25 \times$ normal } \\
\hline Mean & SE & Mean & $\mathrm{SE}$ & Mean & SE \\
\hline $47 \cdot 2$ & $I \cdot 6$ & $45 \cdot 7$ & $1 \cdot 4$ & $44 \cdot 0$ & $\mathrm{I} \cdot 7$ \\
\hline $\begin{array}{l}\text { I } 39 \cdot I \\
3 \cdot 28^{\mathrm{a}}\end{array}$ & $\begin{array}{l}4.3 \\
0.11\end{array}$ & $\begin{array}{c}\text { I } 32.0 \\
3.08^{\mathrm{a}}\end{array}$ & $\begin{array}{l}3.7 \\
0.10\end{array}$ & $\begin{array}{l}10 \mathrm{I} \cdot 3 \\
2 \cdot 04^{\mathrm{b}}\end{array}$ & $\begin{array}{l}3.0 \\
0.09\end{array}$ \\
\hline 189.4 & $I \cdot I$ & $186 \cdot 3$ & $1 \cdot 8$ & $175 \cdot 2$ & $\mathrm{I} \cdot 3$ \\
\hline 35.4 & 0.2 & $19 \cdot I$ & 0.2 & $9 \cdot 6$ & 0.1 \\
\hline $9 \cdot 2^{b}$ & 0.18 & $9 \cdot 0^{\mathrm{b}}$ & 0.21 & $7 \cdot 9^{c}$ & 0.77 \\
\hline $170^{\mathrm{b}}$ & $3 \cdot 2$ & $166^{b}$ & $3 \cdot 9$ & $146^{c}$ & $3 \cdot 2$ \\
\hline $2 \cdot 84^{a}$ & 0.08 & $2 \cdot 93^{a}$ & 0.07 & $3 \cdot 94^{b}$ & 0.15 \\
\hline $2 \cdot 77^{\mathrm{a}}$ & 0.10 & $2 \cdot 64^{\mathrm{a}}$ & 0.08 & $I \cdot 87^{b}$ & 0.07 \\
\hline
\end{tabular}

Deficient

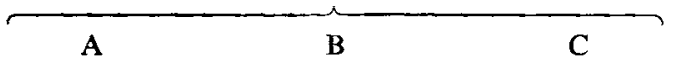

A

C

PER, Protein efficiency ratio ( $\mathrm{g}$ body-wt gain/g protein intake).

$\mathrm{a}, \mathrm{b}, \mathrm{c}$ : Mean values in the same horizontal line with unlike superscripts were significantly different $(P<0.05)$.

- For details, see p. 128.

$\dagger$ For details, see Table I and Fig. I.

\$ Normal P level: $35 \mathrm{mg} / \mathrm{d}$.

\section{RESULTS}

\section{Food intake and growth}

During the pre-experimental period of P-deficiency, the $\mathbf{P}$ and $\mathrm{Ca}$ contents $(\mathrm{g} / \mathrm{kg}$ total DM intake protein + protein-free dietary rations) were 0.22 and 7.8 respectively. On the basis of the actual consumptions of the protein portion of the diet (the only one supplemented with $\mathrm{P}$ ), the daily mean amounts of $\mathrm{P}$ ingested by the control group and treatments $\mathrm{A}, \mathrm{B}$ and $\mathrm{C}$ were $34.4,35.4,19.1$ and $9.6 \mathrm{mg}$ respectively. The $\mathrm{P}$ and $\mathrm{Ca}$ contents ( $\mathrm{g} / \mathrm{kg}$ total DM intake)

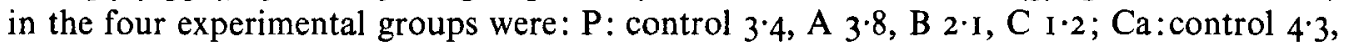
A $4.6, \mathrm{~B}_{4} \cdot 5, \mathrm{C}_{5} 4$.

The animals given a normal amount of $\mathbf{P}$ after a previous deficiency (treatment $\mathrm{A}$ ) had a growth rate similar to that of animals receiving the same amount of $P$ from the beginning of the experiment (control group), i.e. 3.28 and $3.3 \mathrm{I} \mathrm{g/d} \mathrm{respectively.} \mathrm{Furthermore,} \mathrm{a}$ moderate decrease in the supply of $\mathrm{P}$ to a level corresponding to half the normal level (approximately $19 \mathrm{mg} / \mathrm{d}$, treatment $\mathrm{B}$ ), did not bring any statistically significant change either in growth rate or voluntary intake of energy. This was also the situation for the food conversion ratio ( $\mathrm{g}$ DM intake/g body-weight gain, FCR) and the protein efficiency ratio ( $\mathrm{g}$ body-weight gain/g protein intake, PER).

On the contrary, a severe restriction of $\mathrm{P}$ supply (treatment $\mathrm{C}$ ) significantly reduced growth rate and energy intake. FCR was markedly increased and PER was lower.

From these observations a close relationship between the voluntary energy intake and the weight gains recorded in the different treatments was found. This is illustrated in Fig. 2, showing the changes in live weight and food intake during the pre-experimental and experimental periods. The relationship is even more pronounced when considering the change in the energy intake according to the mean live-weight per group and per week 
(Fig. 3). The corresponding values are located almost on the same curvilinear curve whatever the severity of $\mathbf{P}$ deficiency, except for four values from the four groups during the third experimental week. The animals receiving the lowest level of $P$ (treatment $C$ ) showed increasing difficulty in eating the protein ration $(3 \mathrm{~g})$. During the third week, therefore, the amount of protein ration was reduced to $2.5 \mathrm{~g}$ for all the other groups in order to equalize the protein intake. Consequently, there was a temporary levelling of the energy intake which became normal again during the fourth week.

\section{Body composition}

The comparison of body composition values (Table 3) shows a slight difference in water, protein and lipid contents between treatments A and B. Only the ash contents of the whole fat-free carcass decreased from 36.4 to $32.3 \mathrm{~g} / \mathrm{kg}$ when the daily supply of $P$ was reduced to half. On the other hand, when the deficiency in $P$ was more pronounced, not only a more marked decrease in ash content was observed, but also a reduction in fat deposition, and a higher protein content in the tissues. The higher ash content in the carcasses from the control treatment indicated a greater bone mass than in treatment $\mathrm{A}$ which was subjected to a severe deficiency during the pre-experimental period, as demonstrated by the results observed in the PDC group (control treatment subjected to $\mathrm{P}$ deficiency).

On a fat-free fresh weight basis the ash and $\mathrm{Ca}$ contents paralleled each other. This is not surprising since the $\mathrm{Ca}$ content of bone ash is almost constant and the skeleton contains $99 \%$ of the $\mathrm{Ca}$ in the organism. The $\mathbf{P}$ content in the whole organism was almost unchanged when the amount fed was reduced to a half, whereas there was a noticeable decrease when the dietary level represented one-quarter the control level. The differences observed in $\mathrm{K}$ and $\mathrm{Na}$ contents between groups were rather small.

The changes in $\mathrm{Ca}: \mathrm{P}$ for the whole carcass showed very marked differences not only with age but also with the supply of $P$. Thus, in the young rat, immediately after weaning, this value was approximately I (IC group), whereas it reached I.4 in older animals (control treatment and treatment $\mathrm{A}$ ). Furthermore, a relatively greater decrease in $\mathrm{Ca}$ deposition was observed with $P$ deficiency. The retained $\mathrm{Ca}: \mathrm{P}$ recorded in treatment $\mathrm{C}$ at 9 weeks of age was no higher than that of the IC group at only 3 weeks of age.

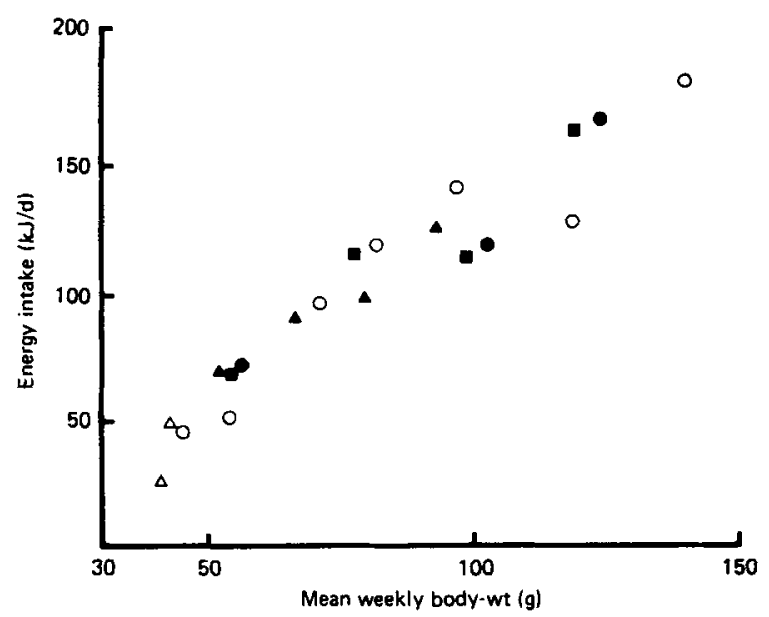

Fig. 3. The effect of voluntary energy intake $(\mathrm{kJ} / \mathrm{d})$ of growing rats in relation to the mean weekly body-weight $(\mathrm{g})$. Each point represents the mean of twelve rats per treatment except for control (ten animals). $\bigcirc$, Control; $\triangle$, initial deficiency; $O$, treatment group A; $\mathbf{\square}$, treatment group B; $\Delta$, treatment group $C$. 


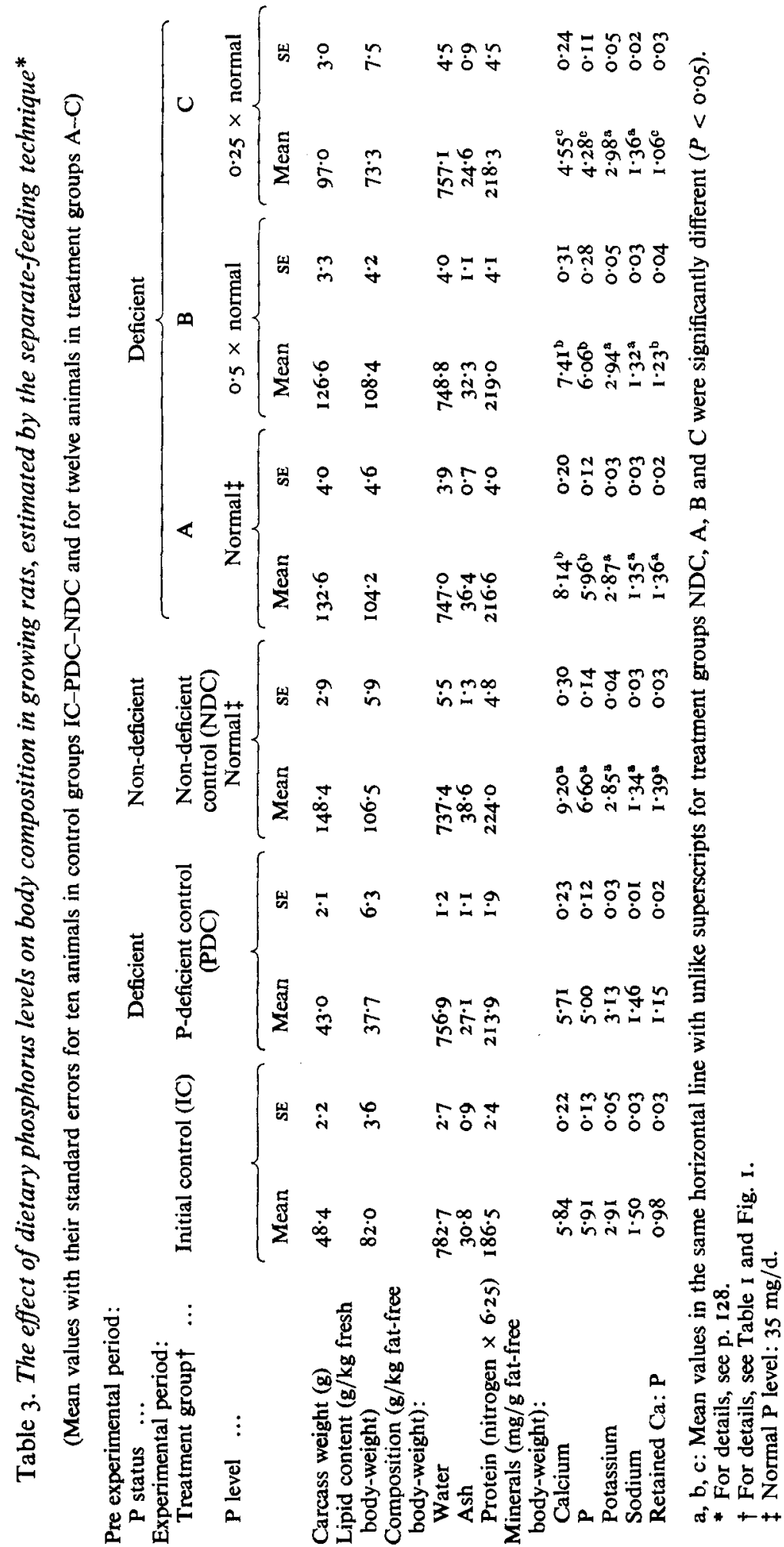


Table 4. The effect of dietary phosphorus levels on nitrogen and energy balance in growing rats, estimated by the separate feeding technique, from calculated body composition (Table 3).

(Mean values with their standard error for ten animals in NDC control group and for twelve animals in treatment groups $\mathrm{A}-\mathrm{C}$ )

Pre-experimental period:

\begin{tabular}{|c|c|c|c|c|c|c|c|c|c|c|}
\hline \multirow{2}{*}{$\begin{array}{l}\text { P status } \ldots \\
\text { Experimental period: } \\
\text { Treatment group } \dagger .\end{array}$} & & Deficient & \multicolumn{2}{|c|}{ Non-deficient } & \multicolumn{6}{|c|}{ Deficient } \\
\hline & $\cdots$ & $\begin{array}{l}\text { Control } \\
\text { (PDC) } \ddagger\end{array}$ & \multicolumn{2}{|c|}{ Control $(\mathrm{NDC})_{+}^{+}$} & \multicolumn{2}{|c|}{ A } & \multicolumn{2}{|c|}{ B } & \multicolumn{2}{|c|}{$\mathrm{C}$} \\
\hline P level $\ldots$ & & Traces & \multicolumn{2}{|c|}{ Normalt } & \multicolumn{2}{|c|}{ Normal§ } & \multicolumn{2}{|c|}{$0.5 \times$ normal } & \multicolumn{2}{|c|}{$0.25 \times$ norma } \\
\hline Balance duration (d) & $\ldots$ & 14 & 4 & & 2 & & 2 & & 2 & \\
\hline $\mathbf{N}$ balance: & & & Mean & SE & Mean & SE & Mean & SE & Mean & SE \\
\hline $\begin{array}{l}\text { Intake }(\mathrm{mg} / \mathrm{d}) \\
\text { Retained: }\end{array}$ & & $139 \cdot 1$ & $190 \cdot 8$ & $\mathrm{I} \cdot 6$ & I 89.4 & $\mathbf{I} \cdot \mathbf{I}$ & $186 \cdot 3$ & $\mathrm{I} \cdot 8$ & $175 \cdot 2$ & $1 \cdot 3$ \\
\hline $\begin{array}{l}\mathrm{mg} / \mathrm{d} \\
\% \mathrm{~N} \text { intake }\end{array}$ & & $\begin{array}{l}2 I \cdot 0 \\
I 5 \cdot 1\end{array}$ & $\begin{array}{l}82 \cdot 6 \\
43 \cdot 3\end{array}$ & & $\begin{array}{l}95 \cdot 9^{8} \\
50 \cdot 6^{\circ}\end{array}$ & $\begin{array}{l}4 \cdot 5 \\
2 \cdot 3\end{array}$ & $\begin{array}{l}90 \cdot 6^{\mathrm{a}} \\
48 \cdot 6^{\mathrm{a}}\end{array}$ & $\begin{array}{l}4 \cdot 6 \\
2 \cdot 4\end{array}$ & $\begin{array}{l}60 \cdot 5^{b} \\
34 \cdot 8^{b}\end{array}$ & $\begin{array}{l}3.8 \\
2 \cdot 4\end{array}$ \\
\hline Energy balance: & & & & & & & & & & \\
\hline $\begin{array}{l}\text { Intake }(\mathrm{kJ} / \mathrm{d}) \\
\text { Retained: }\end{array}$ & & 80 & I 88 & $4 \cdot 3$ & 170 & $3 \cdot 2$ & I 66 & 3.9 & 146 & $3 \cdot 2$ \\
\hline $\begin{array}{l}\mathrm{kJ} / \mathrm{d} \\
\% \text { energy intake }\end{array}$ & & $2 \cdot 5$ & $\begin{array}{l}23 \cdot 9 \\
12 \cdot 7\end{array}$ & & $\begin{array}{l}3 I^{1} \cdot 5^{\mathrm{B}} \\
18 \cdot 4^{\mathrm{A}}\end{array}$ & $\begin{array}{l}1 \cdot 6 \\
0.8\end{array}$ & $\begin{array}{l}30 \cdot 5^{\mathrm{a}} \\
18 \cdot 3^{\mathrm{a}}\end{array}$ & $\begin{array}{l}1 \cdot 4 \\
0.7\end{array}$ & $\begin{array}{l}17 \cdot 0^{b} \\
11 \cdot 8^{b}\end{array}$ & $\begin{array}{l}I \cdot 4 \\
I \cdot I\end{array}$ \\
\hline
\end{tabular}

$\mathrm{a}, \mathrm{b}$ : Mean values in the same horizontal line with unlike superscripts for treatments $\mathrm{A}, \mathrm{B}, \mathrm{C}$ were significantly different $(P<0.05)$.

* For details, see p. 128.

† For details, see Table 1 and Fig. 1 .

$\mp$ Balance results were obtained from the mean values of the given treatment and the initial control group.

$\S$ Normal P level: $35 \mathrm{mg} / \mathrm{d}$.

\section{$N$, energy and mineral retention}

$A$ reduction in the daily supply of $P$ (treatment $B$ ) to half the normal level (treatment $A$ ) only slightly but not significantly reduced $\mathrm{N}$ and energy retention, expressed as absolute or relative values. In contrast, reducing the level to one-quater the normal (treatment $\mathrm{C}$ ) unfavourably affected $\mathrm{N}$ and energy retention (Table 4 ).

The examination of $\mathrm{P}$ and $\mathrm{Ca}$ balance (Table 5) showed that the amount of $\mathrm{P}$ retained in the body was almost the same after administration of either 35 or $19 \mathrm{mg} \mathrm{P} / \mathrm{d}$, whereas it decreased significantly when the daily allowance was reduced to one-quarter the normal level. In relative value, the $P$ retention reached a maximum of $87 \%$ intake with $19 \mathrm{mg} \mathrm{P} / \mathrm{d}$, statistically different from the value observed at the other two P levels.

As could be expected from the chemical body composition analysis, the amount of $\mathrm{Ca}$ retained in the body decreased with the level of $\mathbf{P}$ intake. Since the daily $\mathrm{Ca}$ supply was constant, this resulted in a reduction in the corresponding retention values expressed as a percentage of intake.

\section{DISCUSSION}

\section{Mineral balance and ossification}

The results of the mineral balance are in accordance with the well-known interdependence of $\mathrm{Ca}$ and $\mathrm{P}$ retentions. The efficiency of dietary $\mathrm{Ca}$ retention decreased as the diet contained less $P$, due probably to the competition for $P$ between soft tissues and skeleton. The high retention observed in treatment A compared to the control treatment, for identical dietary supplies, merely resulted from the reduction in bone mineral reserves during the pre-experimental period. Finally, the low efficiency of $\mathrm{P}$ retention in treatment $\mathrm{C}$, which 
Table 5. The effect of dietary phosphorus levels on $P$ and calcium balance in growing rats, estimated by the separate-feeding technique*, from calculated body composition (Table 3)

(Mean values with their standard errors for ten animals in control groups and for twelve animals in treatment

Pre-experimental period: groups A-C)

$$
\text { P status ... }
$$

Experimental period:

Treatment group ...

P level ...

Balance duration (d) ...

$P$ intake $(\mathrm{mg} / \mathrm{d})$

Amount of $P$ in the carcass (mg): Initial

Final

Retained $\mathrm{mg} / \mathrm{d}$ $\% \mathrm{P}$ intake

Ca intake $(\mathrm{mg} / \mathrm{d})$

Amount of $\mathrm{Ca}$ in the carcass (mg): Initial

Final

Retained $\mathrm{mg} / \mathrm{d}$ $\% \mathrm{Ca}$ intake
Deficient Non-deficient

$$
\begin{array}{cc}
\begin{array}{c}
\text { P-defi- } \\
\text { cient }
\end{array} & \begin{array}{c}
\text { Non-de- } \\
\text { ficient }
\end{array} \\
\text { control } & \text { control } \\
\text { (PDC) } \dagger & \text { (NDC) } \dagger \\
\text { Traces } & \text { Normals }
\end{array}
$$$$
14 \quad 42
$$

$$
0.9
$$$$
34 \cdot 4
$$

$225 \cdot 0 \quad 322 \cdot 8$

$208 \cdot 6$

$876 \cdot 7$

$-I \cdot 2 \quad I 3 \cdot 2$

$38 \cdot 4$

$32 \cdot 9$

$43 \cdot 5$

\section{$222 \cdot 6 \quad 319 \cdot 1$}

$238.1 \quad 1224.0$

I. I $21 \cdot 5$

$3.4 \quad 49 \cdot 5$

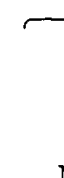

A

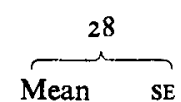

B $0.5 \times$ normal $0.25 \times$ normal
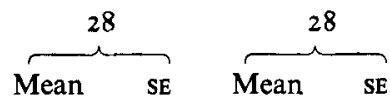

$19 \cdot 1$

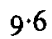

$35 \cdot 4$

$205 \cdot 6$

$667 \cdot 5$

$201 \cdot 8$

705.6

$16.5^{\mathrm{a}} \quad 0.9$

$86.8^{\mathrm{b}} \quad 5 \cdot 2$

$4 \mathrm{I} \cdot 8$

$49 \cdot 3^{\mathrm{a}} \quad 2 \cdot 0$

$44 \cdot 5$

$237 \cdot 2$

$818 \cdot 3$

$25 I \cdot 3$
$963 \cdot 3$

$25 \cdot 4^{\mathrm{a}} \quad \mathrm{I} \cdot \mathrm{O}$

$\begin{array}{ll}56 \cdot 8^{\mathrm{a}} & 2 \cdot 3\end{array}$

$20 \cdot 7^{\mathrm{b}} \quad 1 \cdot 2$

$\begin{array}{ll}44.5^{\mathrm{S}} & 2.8\end{array}$
0.3

$374 \cdot 4$

$\begin{array}{rr}6 \cdot 5^{\circ} & 0.3 \\ 66.9^{c} & 2 \cdot 9\end{array}$

$232 \cdot 8$

$407 \cdot 5$

$6.2^{\mathrm{c}} \quad 0.6$

a, b, c, Mean values in the same horizontal line with unlike superscripts for treatments A, B, C were significantly different $(P<0.05)$.

* For details, see p. I28.

$\dagger$ For details, see Table $\mathbf{I}$ and Fig. I.

$\ddagger$ Balance results were obtained from the mean values of the given treatment and the initial control group.

$\S$ Normal P level: $35 \mathrm{mg} / \mathrm{d}$.

seems paradoxical since the supply was small, might indirectly result from a reduction in bone growth, but this could not be demonstrated since no measurement of bone size could be done.

The results obtained on body mineral composition are in good agreement with the values quoted by Widdowson \& Dickerson (1964). The rat is one of the species with the lowest mineralization at birth. Thus, $\mathrm{Ca}: \mathrm{P}$ in the body increases from approximately 0.9 at birth to an average value of $1 \cdot 7$ in the adult animal (Spray \& Widdowson, I950). The value of I. 4 obtained in 60 -d-old rats fed on the diet with the highest $P$ level (average value $3.5 \mathrm{~g} \mathrm{P} / \mathrm{kg}$ ) thus accounted for a normal bone maturity, whereas the animals receiving the lowest $P$ diets $(\mathrm{I} \cdot 2 \mathrm{~g} / \mathrm{kg})$ exhibited a markedly less developed skeleton.

The intermediate level of $2 \cdot 1 \mathrm{~g} \mathrm{P} / \mathrm{kg}$ that seemed to be sufficient for body growth and food conversion efficiency was not high enough to ensure good bone mineralization. Baylink et al. (I97I) have shown that a dietary P content of $2.0 \mathrm{~g} / \mathrm{kg}$ would bring a moderate hypophosphatemia without any effect on the formation of the bone matrix, but with a significant increase in the osteoclastic resorption.

These observations seem to show that in the rat the minimum requirements for $\mathbf{P}$ during growth, between 40 and $\mathrm{I} 50 \mathrm{~g}$ live-weight, is approximately $20 \mathrm{mg} / \mathrm{d}$, corresponding to $2 \mathrm{mg} \mathrm{P} / \mathrm{g}$ DM. Obviously, for a normal ossification this level has to be increased. It may 
then reach the value recommended by the US National Research Council (1972) under normal feeding conditions.

\section{Regulation of energy intake with P-deficient diets}

In a previous series of experiments (Rérat \& Henry, 1963), involving the separate-feeding technique, it was found that the energy intake in the growing rat is adjusted according to the intensity of protein deposition, which is itself dependent on the quantitative and qualitative protein supply. In the present study, however, for a given amount of dietary protein, the level of energy consumption was severely reduced in P-deficient animals, since it is well known that a lack of dietary $P$ will limit the amount of energy-yielding substances available for protein synthesis (Hegsted, 1974). Nevertheless, there was a close relationship between energy intake and the level of $\mathrm{N}$ retention, which was allowed by the limiting factor for growth. A similar relationship has been found in the instance of B-vitamin deficiency, thiamin or riboflavin (Henry \& Rérat, 1969), or vitamin A deprivation (Blaizot \& Blaizot, I969).

As indicated by the preceding results, a decrease in food intake only occurred when metabolic changes, i.e. a reduced $\mathrm{N}$ retention, were caused by a severe $\mathrm{P}$ deficiency (onequarter of normal level). As long as growth rate was not altered by the deficiency in $P$, neither the voluntary energy intake nor the utilization of energy for tissue formation were affected. Therefore, the slower rate of ossification resulting from $P$ deficiency had no unfavourable effect on protein and energy metabolism. Only the bone P was affected. This clearly shows that the tissue $\mathbf{P}$ has a priority over that of skeleton, so that a deficiency in $\mathbf{P}$ primarily reduces the rate of ossification, resulting in a lower $\mathrm{Ca}$ deposition and a decrease in retained $\mathrm{Ca}: \mathrm{P}$.

On the other hand, when the deficiency in $\mathrm{P}$ was sufficiently pronounced to bring about growth retardation, a lowering effect was observed both on food consumption and protein and energy utilization. In this instance, the tissue $\mathbf{P}$ and that of the skeleton were affected. Taking into account the role of $P$ in energy transport at the cellular level (Hegsted, 1974), it is obvious that there must be a disturbance of protein and energy metabolism.

It can be concluded that inducing a slight $\mathrm{P}$ deficiency in growing rats subjected to separate administration of a protein ration in a limited amount and of a protein-free ration ad lib., primarily affects the density of mineralization of bone (ash weight / unit volume), which decreases considerably, but with only a slight change in growth performance and voluntary energy intake. At a stage of more severe deficiency, the tissue $P$ is affected and the resulting metabolic alterations reduce protein deposition and energy intake. More generally, the level of energy intake in the growing rat fed separately the protein and protein-free fractions of the diet appears to be dependent on the level of protein deposition which is allowed by the limiting factor for growth, either protein, minerals or vitamins.

The authors acknowledge the technical assistance of M. Lecourtier, Mrs Janine Jung, Pierrette Camus and Chantal Blondel. They also wish to thank Mrs Kirsten Rérat for translating this manuscript.

\section{REFERENCES}

Ashley, D. V. M. \& Anderson, G. H. (1975). J. Nutr. 105, 1405. Atwater, W. O. \& Bryant, A. P. (1903). U.S. Dept. Agr. Bull. 28.

Baylink, D., Wergedal, J. \& Stauffer, M. (I971). J. clin. Invest. 50, 2519.

Blaizot, S. \& Blaizot, J. (I969). Annals Nutr. Aliment. 23, 117.

Day, H. G. \& McCollum, E. V. (1939). J. biol. Chem. 130, 269.

Hegsted, D. M. (1974). Nutr, Rev. 32, 33.

Henry, Y. (1968). Annls Nutr. Aliment. 23, 121.

Henry, Y. \& Rérat, A. (1962). Annls Biol. anim. Biochim. Biophys, 2, 267. 
Henry, Y \& Rérat, A. (1963). Annls Biol. anim. Biochim. Biophys. 3, 103.

Henry, Y \& Rérat, A. (1964). C.r. Lebd. Séanc. Acad. Sci., Paris 258, 3915.

Henry, Y. \& Rérat, A. (1966). Amino acides, Peptides et Protéines. Cahiers Alimentation équilibrée de Commentry, vol. 6, p. 240. Commentry, France.

Henry, Y. \& Rérat, A. (1969). Annls Biol. anim. Biochim. Biophys. 9, 601.

Jacquot, R. \& Péret, J. (1972). In Protein and Amino Acid Functions, p. 3 I 7 [E. T. Bigwood, editor]. Oxford: Pergamon Press.

Mayer, J. (1964). In Nutrition: A Comprehensive Treatise, vol. I, p. I [G. H. Beaton and E. W. McHenry, editors]. New York: Academic Press.

Mickelsen, O. \& Anderson, A. A. (1959). J. Lab. clin. Med. 53, 282.

Mitchell, H. H. (1959). In Protein and Amino Acid Nutrition, p. II [A. A. Albanese, editor]. New York: Academic Press.

Musten, B., Peace, D. \& Anderson, G. H. (1974). J. Nutr. ro4, 563.

National Research Council. (1972). Nutrient Requirements of Laboratory Animals. Washington, D.C.: National Academy of Science.

Pearson, E. S. \& Hartley, H. O. (1956). Biometrika Tables for Statisticians, vol. 1, p. I76. Cambridge: Cambridge University Press.

Pol, G. \& Den Hartog, C. (I966). Br. J. Nutr. 20, 649.

Rérat, A. \& Henry, Y. (1963). Annals Biol. anim. Biochim. Biophys. 3, 263.

Rérat, A., Henry, Y. \& Jacquot, R. (1963). C.r. Lebd. Séanc. Acad. Sci. 256, 787.

Rosen, M. \& Levinger, I. M. (1972). Lab. Animals 6, 287.

Rozin, P. (1968). J. comp. physiol. Psychol. 65, 23.

Snedecor, G. W. \& Cochran, W. G. (1967). Statistical Methods Applied to Experiments in Agriculture and Biology, 6th ed. Ames. Iowa: Iowa State University Press.

Spray, E. M. \& Widdowson, E. M. (1950). Br. J. Nutr. 4, 332.

Szepesi, B. \& Oney, M. L. (1977). Nutr. Rep. Int. 16, 59.

Widdowson, E. M. \& Dickerson, J. W. T. (I964). In Mineral Metabolism, vol. 2 A [C. L. Comar \& F. Bronner, editors]. New York: Academic Press. 